\title{
No magic pocket: Buying and selling on drug cryptomarkets in response to the COVID-19 pandemic and social restrictions
}

DOI:

10.1016/j.drugpo.2020.102894

\section{Document Version}

Accepted author manuscript

Link to publication record in Manchester Research Explorer

Citation for published version (APA):

Barratt, M. J., \& Aldridge, J. (2020). No magic pocket: Buying and selling on drug cryptomarkets in response to the COVID-19 pandemic and social restrictions. International Journal of Drug Policy.

https://doi.org/10.1016/j.drugpo.2020.102894

\section{Published in:}

International Journal of Drug Policy

\section{Citing this paper}

Please note that where the full-text provided on Manchester Research Explorer is the Author Accepted Manuscript or Proof version this may differ from the final Published version. If citing, it is advised that you check and use the publisher's definitive version.

\section{General rights}

Copyright and moral rights for the publications made accessible in the Research Explorer are retained by the authors and/or other copyright owners and it is a condition of accessing publications that users recognise and abide by the legal requirements associated with these rights.

\section{Takedown policy}

If you believe that this document breaches copyright please refer to the University of Manchester's Takedown Procedures [http://man.ac.uk/04Y6Bo] or contact uml.scholarlycommunications@manchester.ac.uk providing relevant details, so we can investigate your claim.

\section{OPEN ACCESS}


This is the peer reviewed version of the following article:

Barratt, M. J., \& Aldridge, J. (2020). No magic pocket: Buying and selling on drug cryptomarkets in response to the COVID-19 pandemic and social restrictions. International Journal of Drug Policy

which has been published in final form at https://doi.org/10.1016/j.drugpo.2020.102894

This article may be used for non-commercial purposes in accordance with Elsevier's Article Sharing policy.

(C) 2020. This manuscript version is made available under the CC-BY-NC-ND 4.0 license http://creativecommons.org/licenses/by-nc-nd/4.0/ 
No magic pocket: Buying and selling on drug cryptomarkets in response to the COVID-19 pandemic and social restrictions

Monica J. Barratt ${ }^{\mathrm{a}, \mathrm{b}}$, Judith Aldridge ${ }^{\mathrm{c}}$

a. Social and Global Studies Centre and Digital Ethnography Research Centre, RMIT University, 124 La Trobe Street, Melbourne, Victoria, Australia. monica.barratt@rmit.edu.au

b. National Drug and Alcohol Research Centre, UNSW Sydney, 22-32 King Street, Randwick, New South Wales, Australia.

c. Department of Criminology, University of Manchester, Oxford Road, Manchester M13 9PL, UK. judith.aldridge@manchester.ac.uk

Corresponding author: Monica Barratt.

Submission to the SI: COVID impacts

Keywords: Cryptomarket, Darknet, Drug market, COVID-19, Coronavirus, Routine Activities Theory 


\section{Introduction}

What might be the effects of COVID-19 and the strategies implemented to contain its spread on the illegal drug trade? These strategies include 'lockdowns' in which people have been confined to their homes, alongside recommendations for people to remain at a specified distance from others when they venture out for essential activities, known as 'social distancing'. Will a perception of increased risk of getting caught arising from official attention to dwindling numbers of citizens in public locations function to reduce the willingness of people to engage in the everyday activities entailed in buying and selling illegal drugs? And if so, do drug cryptomarkets - in which buyers and sellers need not transact face-to-face, and where drugs are typically delivered through postal systems - enable the illicit drug trade to continue under lockdown? Drug sales on cryptomarkets, estimated at EUR 750,000 per day from European vendors (Christin \& Thomas, 2019), represent only a small fraction by volume of total global drug trade. And yet because they operate under some different conditions to drug sales involving in-person transactions, cryptomarkets present us with a special case for consideration. Faced with possible shortages in local offline drug markets, do cryptomarkets enable buyers to source drugs from sellers located across the globe that may be unavailable to them from local sellers, and conveniently delivered to them by post, without fear of transgressing lockdown restrictions?

We offer here a framework for anticipating how changes in drug supply and demand arising from global restrictions on the movement of citizens may change how, and the extent to which, drugs are bought and sold on cryptomarket platforms. To begin, we review the possible impacts of COVID-19 and associated social and mobility restrictions on global drug markets more broadly: for supply followed by demand. Then, we address our central question of how drug cryptomarkets may provide opportunities to bypass state-mandated restrictions on movement designed to slow the spread of COVID-19, first considering supply then demand. In conclusion we argue that these capacities will be limited by the ways in which cryptomarkets remain firmly anchored in wider drug markets, and the wider effects of changing supply and demand. We acknowledge the speculative nature of our commentary: our goal here is to prompt new research questions rather than to make predictions. 


\section{COVID-19 and drug markets}

The availability of controlled drugs - whether bought and sold face-to-face or facilitated via online platforms - will inevitably be restricted by COVID-19, especially where those drugs are transported across borders. Like markets for legal products, illicit drug markets rely on local—and often global — distribution modes by air, sea and land, each of which have variously been impacted as a result of global responses to the virus. In particular, some countries that rely more intensively upon air transport for drug supplies are likely to be more severely affected. For example, Dietze and Peacock (2020) note that in Australia, illegal drugs are typically detected at the border via seizures related to air transport: the Australian Criminal Intelligence Commission (2019) reported that air cargo accounted for three quarters of the weight of total seizures of MDMA and cocaine in 2017-18. With reductions in people available for work globally, including in the manufacture and shipping of the legitimate goods in which illegitimate shipments like drugs are concealed, reduced capacity for the trafficking of drugs may follow. Reductions in the number of people using public and private forms of transportation (Google, 2020) further reduces opportunities to shift illicit products, and increases the risks of detection associated with doing so. Retail and social supply will also necessarily be affected when social activities across households are prohibited, making it more difficult and riskier to meet with friends or dealers to exchange drugs for money. Sellers may also fear COVID-19 infection being transmitted via drugs themselves, the packaging or the social context of exchange. Any of these increased costs of drug distribution are likely to increase prices - further reducing drug accessibility, given that a key driver of price is the costs of distribution in consumer countries (Caulkins \& Reuter, 1998). Although COVID-19 itself and the associated social and mobility restrictions appear likely to restrict trade in illegal drugs, the associated global economic downturn could lead to new recruits willing to operate in this higher risk environment, due to a reduction in legal job opportunities. For this same reason, existing suppliers may persist in selling drugs despite fears of infection and perceived increased risk of detection, although in some countries, preoccupation with COVID-19 restrictions may result in reductions in policing of drug supply (United Nations Office on Drugs and Crime [UNODC], 2020).

While most early indicators point toward increased scarcity of illegal drugs (although likely less so for cannabis due to shorter supply chains) (UNODC, 2020), anticipated changes in drug demand 
are less uniformly predictable. A major component of the restrictions associated with COVID-19 is economic recession or contraction. A recent review (Nagelhout et al., 2017) assessed the evidence of five mechanisms through which economic recession may influence illegal drug use, and only found confirmation of an increase in drug use during economic recession due to increased psychological distress. We also know from animal studies that social isolation strongly predicts increased drug demand (Raz \& Berger, 2010). Another reason that demand for drugs may increase is that for people who have become unemployed or furloughed (receiving government payments with no requirement to work or undertake other activities), or who are working from home, may consume more with increased leisure time. Demand for drugs that are typically used in private settings (e.g. cannabis, psychedelics) may increase while stay-at-home orders remain in place. We may, however, also discern pathways under lockdown restrictions leading to decreased demand for drugs. In those countries that lack welfare payments, increasing unemployment may result in less money to purchase drugs and therefore decreased drug use, for example, drug use connected to events in the night-time economy or festivals, including MDMA and others. Furthermore, drugs that people use only in these settings may see a fall in demand because those settings are closed due to social distancing and stay-at-home regulations. The disease itself may reduce drug demand too: people who normally take drugs getting sick or dying from COVID-19, fear of infection from the drugs/packaging/social exchange, and decisions to avoid drug use to improve immunity may all reduce drug demand. Should the decreases in demand described above result in supply gluts where stock is then moved on at a lower price, we may eventually see increased availability and use of some substances.

\section{What is unique about drug cryptomarkets?}

Cryptomarkets are internet sales platforms that host multiple sellers or 'vendors' of drugs for a commission on sales, in return providing marketplace users with anonymity via encrypted communications and payment, alongside vendor reputation metrics arising from aggregated customer feedback ratings (Barratt \& Aldridge, 2016). Unlike in locally-based offline drug markets, the cryptomarket drug trade does not require buyers and sellers to locate one another using existing social networks. Drug buyers' choice of vendors can be informed by more than word-of-mouth: metrics compiled by marketplace platforms based on accumulating customer feedback enables buyers to comparison shop. Buyers and sellers need not transact face-to-face; 
deliveries are made through postal systems or via 'dead drops', where drugs are dropped in a hidden public place, the location of which is sent to the buyer once payment is made. Cryptomarkets enable buyers to source drugs from a wider range of sellers than possible in local markets, and for sellers to reach a wider market than practically possible when conducting trade face-to-face. In spite of this, the cryptomarket trade in illicit drugs tends to be mostly domestic due to the increased risk of detection and loss associated with buying and selling across national borders (Demant, Aldridge, Décary-Hétu, \& Munksgaard, 2018). Still, cryptomarkets enable buyers to source a wider range of drugs than available to them locally, although cannabis and ecstasy-type drugs tend to dominate sales, and while most sales are in personal-use sized quantities, the availability of discounts for bulk quantities makes cryptomarkets a suitable way for

people without existing offline connections to source stock for resale or social supply. Cryptomarket drug trading is not an option for all, relying on users having reliable access to internet connections as well as having the technological skills to effectively use anonymising software (e.g. Tor), and encrypted methods of communication (e.g. PGP) and payment (e.g. currencies like Bitcoin). Moreover, cryptomarkets require buyers to forward plan, typically waiting days or longer from purchase to delivery, although the problem of waiting for delivery does not apply where dead-drop pick-up options are offered and taken up.

\section{COVID-19 and drug cryptomarkets}

Do drug cryptomarkets provide opportunities to bypass state-mandated restrictions on movement designed to slow the spread of COVID-19? We begin with some of the ways in which this may be the case. For sellers trading in-person, if the risks of their trade have increased as described earlier, some may decide to switch their trade from in-person to cryptomarket-facilitated partially to mitigate those increased risks (a shift that has been described pre COVID-19; Martin, Munksgaard, Coomber, Demant, \& Barratt, 2020). Existing cryptomarket vendors may, similarly, experience increased perceived risks of selling, but are unlikely to be as severely affected as in-person sellers. The absence of social exchange in cryptomarket trading and the lack of any need to conduct social interactions outside the home (with travelling outside the home now more intensely surveilled to enforce COVID-19 restrictions) both contribute to lower risks of cryptomarket selling compared to in-person activities in the context of COVID-19 restrictions. Following routine activity theory (Cohen \& Felson, 1979), entry into and maintenance of drug cryptomarket sales may be more 
likely during the COVID-19 restrictions. The daily activities under lockdown for many potentially motivated offenders include increased time spent indoors and online, and compared to selling illegal drugs face-to-face in increasingly surveilled public spaces, will occur in spaces relatively less constrained by suitable guardians. We also know that the most commonly sold drug on cryptomarkets is cannabis (Christin \& Thomas, 2019), which is less likely to suffer from supply chain shocks due to it typically being produced in the country of its consumption. Cryptomarket vendors who sell cannabis may be less adversely affected by supply restrictions, as well as more incentivised by possibly buoyant demand for cannabis during lockdown.

It may also be comparatively more appealing to buy drugs on cryptomarkets than in-person during the COVID restrictions period. Supporting this contention are unpublished interim findings from the UK's Release survey (March-May 2020), of UK drug purchases $(\mathrm{N}=1080)$ where $19 \%$ of cryptomarket purchases (21 of 111) were made by someone new to cryptomarkets (Judith Aldridge, personal communication). In the case where there are drug shortages in people's local networks, access to a wider range of sellers through cryptomarkets will be desirable. These 'new' sellers may be located in the buyer's own country (this is the most likely given what we know about typical cryptomarket structures), but they may also be located elsewhere. While there are increased risks associated with buying from vendors located in other countries, the context of the COVID-19 pandemic may result in a greater willingness to trade across borders. A further reason that cryptomarkets may be more appealing to buyers is that dealers can advertise through detailed text and image communication (Aldridge \& Askew, 2016). During the COVID-19 pandemic, vendors have described their sanitising and cleaning practices in an effort to allay fears that the virus may be transmitted through purchasing their products (Francois Lamy, personal communication). While it is not possible to verify vendors' self-reported hygiene practices, such advertising may provide the kind of information that buyers are looking for, and therefore be more attractive to buyers.

While we have argued here that cryptomarkets may provide some limited but important opportunities to bypass the COVID-19 restrictions, those opportunities may not be enough to counteract global drug supply contractions, where these occur. The relative appeal of cryptomarkets is only valid to the extent that drug supplies remain to be traded and where demand 
remains buoyant. If those supplies become very difficult or impossible for vendors to source for cryptomarket resale, no features of the cryptomarkets ecosystem will be enough to counteract that. Indeed, if overall cryptomarket drug sales fall significantly due to a lack of available product, profits flowing to the market administrators will also fall. Combined with increases in the costs of doing business related to increased cyber-crime associated with COVID-19 restrictions (e.g. securing the platform from attack) (Europol, 2020), we may see more administrators looking to exit by closing their markets altogether. Emerging evidence suggests that cryptomarkets may facilitate (or simply reflect) use by buyers for stockpiling in response to lockdown measures. Data

collected from three cryptomarkets showed overall sales of cannabis fell between January and March 2020, but that this overall trend comprised two drivers: decreases in bulk sales and increases in retail-level sales (European Monitoring Centre for Drugs and Drug Addiction, 2020). It is too early to tell what the overall effects of COVID-19 will be on cryptomarket sales volume. The complex interactions of the possible effects we have outlined will also relate to the varied features of the COVID-19 responses within and across countries, and, as outlined by Giommoni (2020), by their duration, intensity, timing and context. That is, much will depend on the path of the pandemic and the severity and length of the social restrictions associated with COVID-19 across different contexts.

\section{Conclusion}

Cryptomarkets do not provide buyers with a 'magic pocket' for drugs unavailable elsewhere due to lockdown, since — whether traded online or offline - drugs must ultimately be sourced offline, even if cryptomarkets may enable buyers to access a wider range of sellers than otherwise. While there are some features of cryptomarkets that may enable the bypass of aspects of these effects, and may be more attractive during the COVID-19 era to buyers or sellers, the market forces on supply and demand still apply to the supplies and demands attached to cryptomarkets. There are many unknowns here, however, but the unprecedented illicit drug market supply shocks created by government responses to COVID-19 globally provide researchers collecting the rich, detailed and powerful datasets arising from cryptomarket drug selling a valuable opportunity to test these and other hypotheses. 


\section{References}

Aldridge, J., \& Askew, R. (2016). When drug dealers can advertise: How drug cryptomarkets enable drug dealers to advertise. Paper presented at the 10th Annual Conference of the International Society for the Study of Drug Policy, Sydney, Australia.

Australian Criminal Intelligence Commission. (2019). Illicit drug data report 2017-18. Canberra: Commonwealth of Australia.

Barratt, M. J., \& Aldridge, J. (2016). Everything you always wanted to know about drug cryptomarkets* (*but were afraid to ask) [Editorial]. International Journal of Drug Policy, $35,1-6$.

Caulkins, J. P., \& Reuter, P. (1998). What price data tell us about drug markets. Journal of Drug Issues, 28, 593-612.

Christin, N., \& Thomas, J. (2019). Analysis of the supply of drugs and new psychoactive substances by Europe-based vendors via darknet markets in 2017-18. Lisbon: EMCDDA.

Cohen, L. E., \& Felson, M. (1979). Social change and crime rate trends: A routine activity approach. American Sociological Review, 44, 588-608.

Demant, J., Aldridge, J., Décary-Hétu, D., \& Munksgaard, R. (2018). Going local on a global platform: A critical analysis of the transformative potential of cryptomarkets for organized illicit drug crime. International Criminal Justice Review, 28, 255-274.

Dietze, P. M., \& Peacock, A. (2020). Illicit drug use and harms in Australia in the context of COVID-19 and associated restrictions: Anticipated consequences and initial responses. Drug and Alcohol Review, 39, 297-300.

European Monitoring Centre for Drugs and Drug Addiction. (2020). COVID-19 and drugs: Drug supply via darknet markets. Lisbon: EMCDDA.

Europol. (2020). Catching the virus: Cybercrime, disinformation and the COVID-19 pandemic. The Hague, NL: European Union Agency for Law Enforcement Cooperation.

Giommoni, L. (2020). Why we should all be more careful in drawing conclusions about how coronavirus is changing drug markets. International Journal of Drug Policy, In press.

Google. (2020). COVID-19 Community Mobility Reports. Retrieved 14 May, 2020, from https://www.google.com/covid19/mobility/ 
Martin, J., Munksgaard, R., Coomber, R., Demant, J., \& Barratt, M. J. (2020). Selling drugs on darkweb cryptomarkets: Differentiated pathways, risks and rewards. British Journal of Criminology, 60, 559-578.

Nagelhout, G. E., Hummel, K., de Goeij, M. C. M., de Vries, H., Kaner, E., \& Lemmens, P. (2017). How economic recessions and unemployment affect illegal drug use: A systematic realist literature review. International Journal of Drug Policy, 44, 69-83.

Raz, S., \& Berger, B. D. (2010). Social isolation increases morphine intake: Behavioral and psychopharmacological aspects. Behavioural Pharmacology, 21, 39-46.

United Nations Office on Drugs and Crime. (2020). COVID-19 and the drug supply chain: From production and trafficking to use. Vienna: UNODC. 